\title{
Improving students' speaking skill through storytelling at the tenth grade of SMA Al-Kautsar Bandarlampung
}

\author{
Khairani Putri Salsya ${ }^{1}$, Mahpul $^{2}$, Rafista Deviyanti ${ }^{3}$ \\ Universitas Lampung, Jl. Prof. Dr. SumantriBrojonegoro, Rajabasa, Bandarlampung ${ }^{1,2,3}$ \\ ${ }^{1}$ Correspondence: salsyaputri@gmail.com
}

\begin{abstract}
The objectives of this research were to find out whether there is an improvement of the students' skill in speaking English after being taught of storytelling technique and to find out the students' perception toward the implementation of storytelling technique. The approach of the research was quantitative. The subjects were 30 students of class X IPS2 at SMA Al-Kautsar Bandar Lampung in 2019/2020 academic year. Speaking tests and questionnaires were used to collect the data. The students' speaking scores were compared between the pre-test and the post-test by using Paired Sample T-test with the significant leve 10,000. The students' perception toward the implementation of storytelling technique were 0.754 . The result of the research showed that there was an improvement of the students' speaking skill from the pre-test (56.73) to the post-test (68.25). It can be seen from the students' mean score after the implementation of storytelling technique improved at11.52. Furthermore, the result of questionnaires showed that most students gave positive perception toward the implementation of storytelling technique in improving students' speaking skill. This suggests that storytelling technique can be used as a strategy to improve the students' speaking skill.
\end{abstract}

Keywords : storytelling technique, speaking skill, students' perception.

\section{INTRODUCTION}

According to Richard (2008:19), the mastery of speaking skill in English is a priority for many second-language or foreign language learners. He said that speaking is a primary basic skill to tell and share ideas in communication. Thus, speaking is one of the language skills that must be learned to start the communication.

Speaking is the productive skill. It cannot be separated from listening. When we speak, we produce the text and it should be meaningful. In the nature of communication, we can find the speaker, the listener, the message and the feedback. Speaking cannot be separated from pronunciation as it encourages learners to learn the English sounds. Considering the importance of mastering the speaking skill in language teaching, the national policy through the regulation of minister of national education reflects the importance of English in the standard of content. Also, Indonesia establishes English as prominent foreign language taught at school and one of subjects tested in national exam. This determination is intended to prepare Indonesian students in facing 
globalization era. For this reason, a suitable technique needs to be used in this research; therefore, researcher has to find out the techniques which can be used in teaching speaking. One of them is storytelling technique.

According to Harmer (2007:89), storytelling is one of methods in teaching speaking that students can briefly summarize a tale or story they heard from somebody beforehand, or they may create their own stories to tell their classmates. So, the students can share their ideas in storytelling. The researcher chooses storytelling technique because there are several purposes, such as; students can improve their speaking skill, and try new interesting technique that makes students enjoy in learning teaching process. This storytelling technique, have been applied in many studies. According to Akhyak and Indramawan (2013: 18) in the study entitled "Improving the students' English speaking competence through storytelling". Then, the study entitled "A story-telling approach to teaching English to young EFL Iranian learners" by Kalantari and Hashemian (2015: 221). Through their research, it is found that storytelling technique can improve students' speaking skill significantly. This technique has their own characteristic and advantages in improving students' speaking skill.

Furthermore, the researcher conducted this research to investigate the improvement of students' skill in speaking English after being taught of storytelling technique. Thus, the researcher tried to make this research different with the previous studies by adding students' perception of the techniques as the feedback for the researcher. The researcher uses questionnaire to measure students' point of view toward the technique. Based on some reasons above, it is worth investigating the improvement of students' speaking skill in after being taught of storytelling technique and also the students' perception toward the technique.

\section{METHODOLOGY}

This research adopts a quantitative approach with one group pre-test post-test design, in which there is one group as the sample (Setiyadi, 2018). The population for this research is the students at the first grade of SMA Al-Kautsar Bandar Lampung in academic year 2019/2020. For the sample, the researcher chooses 30 students from X IPS 2 by using purposive sampling. The data are collected by using tests (pre-test and post-test) and questionnaire. Then, the improvement of students' test results are analyzed by using paired sample t-test in SPSS ver. 16 to find out whether any improvement of students' speaking skill. Meanwhile, to know the students' perception after the implementation of mind mapping technique the researcher computes the data by using SPSS ver. 16 then analyzes it descriptively.

\section{RESULTS AND DISCUSSIONS}

\section{Results}

After conducting the research, the researcher gathers the result of the pre-test and post-test after the implementation of storytelling technique. Table 1 shows the improvement of students' speaking skill from pre-test to post-test. 
Table 1. Students' Improvement

\begin{tabular}{|c|c|c|c|}
\hline Story & Pre-test & Post-test & Improvement \\
\cline { 2 - 4 } Telling & 56.73 & 68.25 & 11.52 \\
& & & \\
\hline
\end{tabular}

Table 1 above, it can be seen that the gain of the students' scores after the implementation of storytelling technique improved at 11.52. It means that students have better scores in the post-test.

Table 2. The Difference of Students' Pre-test and Post-test Score in Paired Samples Statistics

Paired Samples Test

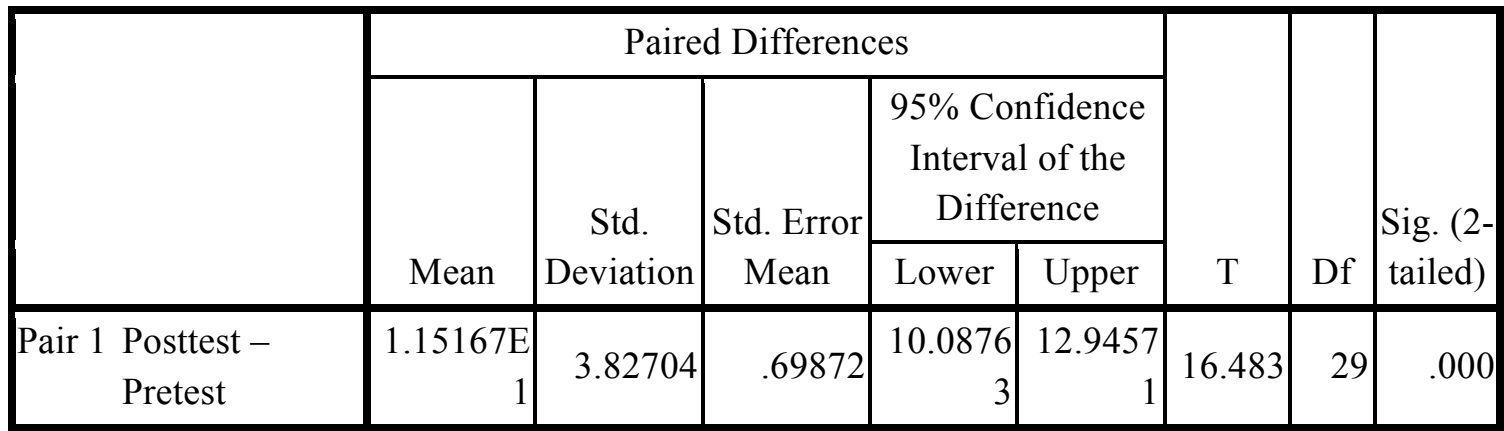

Table 2 provides evidence that the mean difference of students' speaking score in post-test and pretest is significant since the significant (2-tailed) is lower than 0.05. It indicates that after the implementation of storytelling, students' speaking skill significantly improved.

\section{Chart 1. Students' Perception of Storytelling Technique}

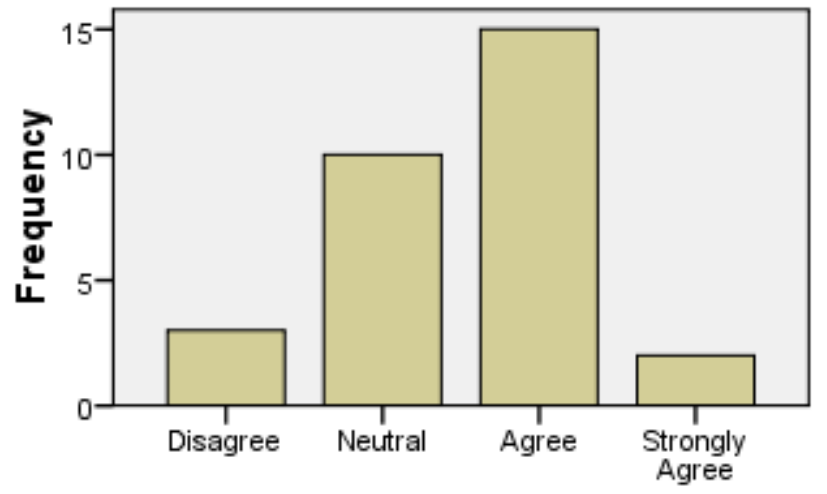

It can be seen from the chart above that most students (15 students) of SMA Al-Kautsar Bandarlampung agree that through storytelling technique they are confident to speak English and can improve their speaking skill. The number of students who have agreed perception of storytelling technique is more than they who have disagreed perception ( 3 students).

\section{Discussions}

1. The Improvement and the Significant Difference on Improving Students' Speaking Skill through Storytelling Technique, 
This current study which involves 30 students class provides evidence that the implementation of storytelling technique can improve the students' speaking skill. It can be seen from the gain of the students' pre-test and post-test scores in table 1 shows that the improvement of students' pre-test to post-test. It indicated that all of the students' scores increased from the pre-test to the post-test.

Besides, it can be seen from table 2 shows that there is a significant difference on students' speaking skill after being taught of storytelling technique. It proved that storytelling technique helps students to improve their' speaking skill significantly, and storytelling is an interesting technique to improve students' speaking skill. It is supported by Irawati, S. (2003) says that story telling is an oral activity where language and gestures are used in a colorful way to create scenes in a sequence however, storytelling consists of more than just story telling.

While conducting the research, part of storytelling process that affects much in students' improvement from pre-test to post-test was in process of speaking through storytelling technique. During the pre-test, some of students found difficulty to express their ideas to speak English well. While the treatment on the implementation of storytelling technique, the improvement on students' speaking skill improved especially when the researcher implemented storytelling technique in class then, the students did storytelling based on their hometown story.

The students were enthusiast and interested in storytelling technique because during the research they could express more their ideas to speak in front of their classmates. They tried to share their hometown story to the others and it makes the others were interested in the treatment process.

The finding above is in line with Harmer (2007) who stated that storytelling is one of methods in teaching speaking that students can briefly summarize a tale or story they heard from somebody beforehand, or they may create their own stories to tell their classmates. So, the students can share their ideas in storytelling.

In addition, it was also found that storytelling technique successfully improved each aspect of students' speaking skill by Harris (1969), they are pronunciation, grammar, vocabulary, fluency, comprehension.

Before getting the treatments, the students had difficulties in conveying their ideas by speaking. It made their speaking lack of 5 aspect of speaking. However, after getting the treatments, their speaking became better and smoother.It means that it is good for the students because storytelling helps the students to organize and create the ideas as many as they can before they speak. That makes the students can be easily to speak because they only need to elaborate the ideas. So, storytelling is useful for the students to do speaking and the students in this research were helped in speaking English through storytelling technique. 


\section{Students' Perception toward the Implementation of Storytelling Technique}

The result of the students' perception questionnaire that has been given after the implementation of storytelling technique shows that most of students gave positive perception to statements of the questionnaire.

Based on the result of the data analysis, chart 1 shows that out of 30 students, 15 students had agreed perception and 3 students had disagreed perception, the other had strongly agreed (2), neutral (10) perception toward the implementation of storytelling technique. Thus, the majority of the students asserted that the implementation of storytelling technique was very good for them and helped them in learning speaking. It is supported by Fikriah (2016) who had observed that the students' English speaking skills is effectively improved through storytelling.

Related to the answer of the students, it showed that storytelling gave advantages for the students. Firstly, storytelling made students confident to speak English. Secondly, storytelling technique made students interested in speaking learning teaching process. Thirdly, it helped students to improve their speaking skill.

\section{CONCLUSIONS AND SUGGESTIONS}

\section{Conclusions}

The objectives of this research were to investigate whether the implementation of storytelling techniques can improve students' speaking skill or not and find out students' perception of storytelling technique. Based on the result and discussion, it can be concluded that the implementation of storytelling technique was effective to improve students' speaking skill. It could be seen from the improvements of students' writing mean score in the pre-test and post-test $(56.73$ to 68.25). So, it can be concluded that the treatments using storytelling technique was more helpful to improve speaking skill. All students had different perception after the implementation of storytelling technique. Out of 30 students, 15 students had agreed perception and 3 students had disagreed perception, the other had strongly agreed (2), neutral (10) perception. The students' perception about the implementation of storytelling technique in class activity is positive.

\section{Suggestions}

Referring to the conclusion above, the researcher would like to recommend some suggestions. Suggestions for English teachers, It is suggested for English teachers to apply storytelling technique as one of the alternative ways to increase the students' speaking skill. This is because story telling technique can help the students who still have the problems in expressing their ideas in speaking English well by using 5 aspect of speaking. English teachers are also suggested to use media in teaching speaking by storytelling technique while the treatments, such as: pictures, videos, and dolls. It is because most of the students are more excited when the teacher uses media in teaching learning activity. Besides, the activities in the class will be more fun. Suggestions for further researchers, this study was conducted in a senior high school level. Therefore, further researchers can try to find out the use of storytelling technique in different level of schools. This study was 
aimed to find the students' perceptions after the implementation of storytelling technique in the class. Therefore, further researcher can try to find out the responses, motivation or attitude of the students.

\section{REFERENCES}

Akhyak \& Indramawan, A. (2013). Improving student's English speaking competence through storytelling (Study in Pangeran Diponegoro Islamic College (STAI) of Nganjuk, East Java, Indonesia). International Journal od Language and Literature.

Fikriah. (2016). Using the storytelling technique to improve English speaking skills of primary school students. English Education Journal (EEJ).

Haris, David P. 1969. Testing English as a second language. New York: McGraw Hill.

Harmer, Jeremy. (2007). How to teach English. China: Pearson Education Limited.

Harmer, Jeremy.(2007)The practice of English in language teaching. Harlow: Pearson Longman.

Irawati, S. (2003). The use of newspaper in teaching speaking for SMU Students in SMU 97 Jakarta. Jakarta: The University of Jakarta.

Kalantari, F. \& Hashemian, M. (2015). A story-telling approach to teaching English to young EFL Iranian learners. Journal of English Language Teaching.

Setiadi, A. B. (2006). Metode penelitian untuk pengajaran bahasa asing pendekatan kuantitatif dan kualitatif. Yogyakarta: Graha Ilmu

U-JET, Vol 9, No 3, 2020 